\title{
Soil carbon and nitrogen sequestration over an age sequence of Pinus patula plantations in Zimbabwean Eastern Highlands
}

\author{
L. Mujuru ${ }^{\mathrm{a}, \mathrm{b}, *}$, T. Gotora ${ }^{\mathrm{c}}$, E.J. Velthorst ${ }^{\mathrm{a}}$, J. Nyamangara ${ }^{\mathrm{d}}$, M.R. Hoosbeek ${ }^{\mathrm{a}}$ \\ ${ }^{a}$ Wageningen University, Dept. of Environmental Sciences, Earth System Science, P.O. Box 47, 6700 AA Wageningen, The Netherlands \\ ${ }^{\mathrm{b}}$ Bindura University of Science Education, Dept. of Environmental Science, P. Bag 1020, Bindura, Zimbabwe \\ ${ }^{\mathrm{C}}$ Carbon Africa Ltd. - Zimbabwe, No. 6 Devonshire, J. Chinamano Road, Harare, Zimbabwe \\ ${ }^{\mathrm{d}}$ International Crops Research Institute for the Semi-Arid Tropics (ICRISAT), Matopos Research Station, P.O. Box 776, Bulawayo, Zimbabwe
}

\section{A R T I C L E I N F O}

\section{Article history:}

Received 6 October 2012

Received in revised form 6 November 2013

Accepted 19 November 2013

\section{Keywords:}

Soil organic matter fractions

Forest floor

C:N ratios

Plantation forestry

Carbon

\begin{abstract}
A B S T R A C T
Forests play a major role in regulating the rate of increase of global atmospheric carbon dioxide $\left(\mathrm{CO}_{2}\right)$ concentrations creating a need to investigate the ability of exotic plantations to sequester atmospheric $\mathrm{CO}_{2}$. This study examined pine plantations located in the Eastern Highlands of Zimbabwe relative to carbon (C) and nitrogen (N) storage along an age series. Samples of stand characteristics, forest floor (L, F and H) and 0-10, 10-30 and 30-60 cm soil depth were randomly taken from replicated stands in Pinus patula Schiede \& Deppe of $1,10,20,25$, and 30 years plus two natural forests. Sodium polytungstate (density $1.6 \mathrm{~g} \mathrm{~cm}^{-3}$ ) was used to isolate organic matter into free light fraction (fLF), occluded light fraction (oLF) and mineral associated heavy fraction (MaHF). In both natural and planted forests, above ground tree biomass was the major ecosystem $\mathrm{C}$ pool followed by forest floor's humus $(\mathrm{H})$ layer in addition to the $45 \%, 31 \%$ and $24 \%$ of SOC contributed by the $0-10,10-30$ and $30-60 \mathrm{~cm}$ soil depths respectively. Stand age caused significant differences in total organic $\mathrm{C}$ and $\mathrm{N}$ stocks. Carbon and $\mathrm{N}$ declined initially soon after establishment but recovered rapidly at 10 years, after which it declined following silvicultural operations (thinning and pruning) and recovered again by 25 years. Soil $\mathrm{C}$ and $\mathrm{N}$ stocks were highest in moist forest $\left(18.3 \mathrm{~kg} \mathrm{C} \mathrm{m}^{-2}\right.$ and $0.66 \mathrm{~kg}_{\text {of N m}}{ }^{-2}$ ) and lowest in the miombo $\left(8.5 \mathrm{~kg} \mathrm{~m}^{-2}\right.$ of $\mathrm{C}$ and $0.22 \mathrm{~kg}$ of $\mathrm{N} \mathrm{m}^{-2}$ ). Average soil $\mathrm{C}$ among Pinus stands was $11.4 \mathrm{~kg}^{-2} \mathrm{C} \mathrm{m}^{-2}$, being highest at 10 years (13.7 of

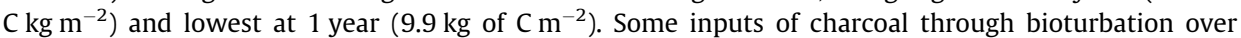
the 25 year period contributed to stabilisation of soil organic carbon (SOC) and its depth distribution compared to the one year old stands. Nitrogen was highest at 10 years $\left(0.85 \mathrm{~kg} \mathrm{of} \mathrm{N} \mathrm{m}^{-2}\right)$ and least at 30 years $\left(0.22 \mathrm{~kg}\right.$ of $\left.\mathrm{N} \mathrm{m}^{-2}\right)$. Carbon and $\mathrm{N}$ in density fractions showed the 20 year old stand having similar proportions of fLF and oLF while the rest had significantly higher fLF than oLF. The contribution of fLF C, oLF C and MaHF C to SOC was $8-13 \%, 1-7 \%$ and $90-91 \%$ respectively. Carbon and $\mathrm{N}$ in all fractions decreased with depth. The mineral associated $\mathrm{C}$ was significantly affected by stand age whilst the fLF and oLF were not. Conversion of depleted miombo woodlands to pine plantations yield better $C$ gains in the short and long run whilst moist forest provide both carbon and biodiversity. Our results highlight the importance of considering forestry age based $C$ pools in estimating $C$ sink potential over a rotation and the possibility of considering conservation of existing natural forests as part of future REDD + projects.
\end{abstract}

(c) 2013 Elsevier B.V. All rights reserved.

\section{Introduction}

Changes in soil organic matter (SOM) can result in significant contributions to emissions or uptake of greenhouse gases from forests and other land use systems. Forests govern $C$ transfers directly through photosynthesis and respiration and indirectly by influencing the structure and size of plant-leaf development (Eliasson,

\footnotetext{
* Corresponding author at: Bindura University of Science Education, Dept. of
} Environmental Science, P. Bag 1020, Bindura, Zimbabwe.

E-mail address: mujuru2004@yahoo.co.uk (L. Mujuru).
2007; Van Minnen, 2008). They represent an important C pool (Brown, 2002) that favour sequestration of $C$ due to their increased woody biomass, extensive roots, and abundant litter (Sharrow and Ismail, 2004). The extensive rooting system of forest species influence soil microbial biomass thus control the cycle of $C$ between the atmosphere and the soil (Brown, 2002). In general, tropical forests contain less $C$ in soils than their biomass $C$, storing about $60 \% \mathrm{C}$ aboveground and 40\% belowground (Dixon et al., 1994). However, especially in these forests, roots go deeper and thus, root turnover may add to $C$ sequestration in deeper horizons due to slow carbon turnover (Jobbagy and Jackson, 2000). 
The accumulation of soil $\mathrm{C}$ and $\mathrm{N}$ varies within different soil horizons and depths. Some forest sub soils hold about $45 \%$ of total SOC bound to the clay particles to form microaggregates. This complexion of SOC in the forest sub soils is essential for long-term stabilisation (von Lützow et al., 2006). The extent of this stabilisation is determined by organo-mineral interactions, micropores, type and nature of clay surfaces, and $C$ location within the microaggregates.

Next to climate and soil type, the sequestration of $C$ depends on forest species and management (Lal, 2003; Lamlom and Savidge, 2003) having a compromise between ecosystem C storage capacity and timber extraction. Long-term differences in SOC storage among three tree species have been studied by Seely et al. (2002) who concluded that all tree species are important $C$ pools although they have different C storage capacities. Vesterdal et al. (2002) compared soils under Norway spruce (Picea abies L) and oak (Quercus robur L.) and showed them to sequester $0.9 \mathrm{~kg} \mathrm{~m}^{-2}$ of $\mathrm{C}$ and $0.2 \mathrm{~kg} \mathrm{~m}^{-2}$ of $\mathrm{C}$ respectively after 29 years and the SOC being mostly concentrated in the upper soil horizons. In Hawai, Kaye et al. (2000) reported storage of C by 17-year old Eucalyptus and Albizia lebbeck trees and reported that Albizia had $2 \mathrm{~kg} \mathrm{~m}^{-2}$ more soil $\mathrm{C}$ and $0.230 \mathrm{~kg} \mathrm{~m}^{-2}$ more soil $\mathrm{N}$. The greatest potential for above ground biomass $C$ storage in coniferous plantations (e.g. pines) is found in tree biomass (Peichl and Arain, 2006) with additional amounts from forest floor and mineral soil C (Taylor et al., 2007; Noh et al., 2010). Net rate of $C$ uptake is greatest when forests are young, and slows with time. Old forests continue to sequester $C$ at a decreased rate with decreased rate of respiration (Marris, 2008). When forests are cut, $\mathrm{C}$ is returned quickly to the atmosphere if the woody tissue is burned or converted to products that are short-lived (Ecological Society of America, 2000). Depending on harvesting practices, most of soil $\mathrm{C}$ remains in the soil and become part of the $C$ stock of growing forest or a subsequent cycle in a plantation system. In addition to type of tree species, stand age is also critical in determining the amount of $C$ in an ecosystem influencing the quality and quantity of $C$ inputs released into an ecosystem (Matos et al., 2010; Penne et al., 2010). Some studies have shown that conversion of native forests to conifers can cause up to $15 \%$ losses of SOC depending on period following conversion while others estimated up to $20 \%$ SOC reductions over periods below 40 years (Guo and Gifford, 2002).

The general impacts of plantation forests have been outlined by region (Nilsson and Schopfhauser, 1995) and the IPCC (2003) suggested that the real $\mathrm{C}$ stock estimates might be much lower than indicated as some of the $\mathrm{C}$ has not been accounted for. Some studies have indicated relative increases in surface soil C stocks in plantations (Schwertmann et al., 1986) while other studies found limited capacity for soil C accumulation (Richter et al., 1999; Liao et al., 2012). In this study we will not only look at quantities of $\mathrm{C}$ but also at its stability. Next to quantity, type and degree of stabilization is also important for the assessment of $\mathrm{C}$ sequestration.

Most studies on soil $\mathrm{C}$ and $\mathrm{N}$ dynamics over stand age are mainly from other regions either from experimental stations reflecting site specific conditions e.g. (Covington, 1981; Rita et al., 2011) or model estimations on a local or regional scale e.g. (Peltoniemi et al., 2004). Forest systems of Zimbabwe include rainforest, indigenous woodlands, plantations and bushland/grasslands covering $0.1 \%, 65.9 \%, 0.4 \%$ and $1.5 \%$ of the land area respectively. Plantation forests consist of Pinus spp. (68\%), Eucalyptus (20\%) Acacia mearnsii (11\%) and Poplar spp. (1\%) (Forestry Commission Zimbabwe, 1996). The relatively extensive woodland cover makes it a potential $\mathrm{C}$ sink, but it is threatened by agricultural expansion and demand for wood.

The characterisation of $C$ in the above ground biomass of forests is well advanced, but the below ground $C$ dynamics is poorly understood causing a need for correlating the below ground biomass to the above ground biomass to predict $C$ storage in forest soils (Brown, 2002). Determination of the flux of global C cycle needs substantial research which can link patterns and long term effects of $\mathrm{C}$ and $\mathrm{N}$ accumulation in the soil relative to forest age. The role of forests in the global $\mathrm{C}$ cycle has therefore initiated great interest in exploring the capacity of forest ecosystems to increase $\mathrm{C}$ uptake by means of afforestation and sustainable forest management through initiatives such as reduced emissions form forest degradation and deforestation (REDD+). There are few studies quantifying the potential for soil $\mathrm{C}$ accumulation and stabilisation under natural and exotic plantations in Zimbabwe and this creates a need for studies on the soil $C$ sink potential of forest plantations. Reliable knowledge of the $\mathrm{C}$ and $\mathrm{N}$ dynamics in forest soils is therefore fundamental to understanding sustainable forest management practices and their role in climate change mitigation.

In this study we measured forest floor and soil $\mathrm{C}$ and $\mathrm{N}$ pools induced by plantation forestry at different stages during a rotation cycle. Our aim was to describe the distribution, accumulation, stability of forest floor and soil $\mathrm{C}$ and $\mathrm{N}$ pools and their temporal shifts over time. We hypothesise that (1) forest floor and soil C pools under plantation forestry are lower than natural forest, (2) more $C$ is stored in the forest floor and soil pools with increasing stand age within a cycle and (3) soil C stabilisation increases with stand age.

\section{Study site and methodology}

The study was carried out within the Nyanga Pine Division of Wattle Company P/L in Eastern Zimbabwe at Mutarazi Estate situated at S19 01.032 E32 35.810, lying at the extreme South of the Nyanga District (Fig. 1). The altitude ranges between $1020 \mathrm{~m}$ and $1920 \mathrm{~m}$ above sea level. The terrain is characterised by relatively moderate slopes, and forms part of the Eastern escarpment of the Nyanga mountain range. It is drained mainly by the perennial Mutarazi river. The total plantation area is 3,806,990 ha of which 2548 ha was re-planted as at September 2010 (WATCO, 2010).

Mutarazi Estate falls into Natural Region (NR) I of the Zimbabwe agro ecological classification system (WATCO, 2010) with annual rainfall estimated at around $1500 \mathrm{~mm}$ and the seasonality follows the same general pattern as the rest of the country (bulk of rainfall being confined to the months of November to March). Small amounts of winter precipitation in the form of mist, fog and rainfall do occur on areas of high elevation. Average maximum temperature is $28^{\circ} \mathrm{C}$ with a minimum of $0{ }^{\circ} \mathrm{C}$. Lowest temperatures occur between May and August while the highest are from October to February. Relative humidity varies between mean 58\% in September to a mean of $86 \%$ in January/February. The prevailing wind is easterly blowing dominantly during the months of November to May.

The soils are orthoferrallitic within the Kaolinitic order (Zimbabwean classification) which corresponds to Rhodic ferralsols in FAO classification (FAO, 2006). The soils are characterised by good depth, permeability and structural stability exhibiting a high degree of resistance to erosion. They have extremely poor chemical characteristics, with particularly high levels of acidity and low weathering rates (WATCO, 2010).

A wide variety of broadleaf, large tree species occur in natural forests including Macaranga mellifera, Ilex mitis, Schrebera alata, Rapanea melanophloeos, Olea capensis and Schefflera umbellifera. The understorey of these forests is usually dominated by extensive banks of ferns comprising mainly of Asplenium and Cyathea spp. Widespread stands of Psychotria zombamontana also occur. Forest fringes are dense dominated by species including Hypericum revolutum, Pteridium, Rubus and Smilax anceps. These forests are usually 


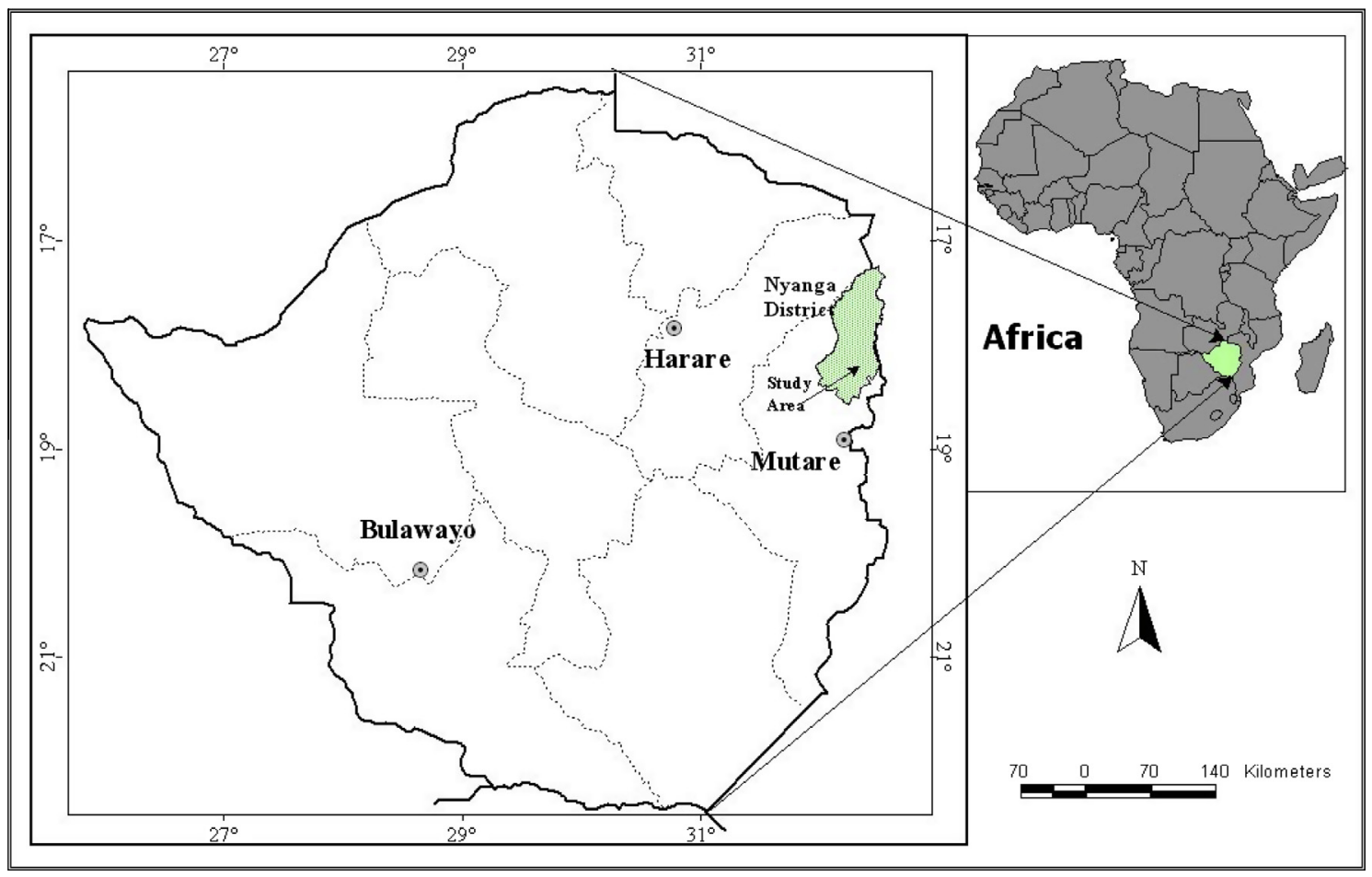

Fig. 1. Map of Zimbabwe showing the location of Nyanga pine's Mutarazi forest.

protected from invasions by commercial pine species and from fires by wide fire guards (20-50 m) and inside fire traces. Individual compartment records showed that natural forests were cleared for establishment of pine plantations in all stands considered for the study (WATCO, 2010).

Mutarazi estate is made up of 14 blocks with a total of 206 compartments of pine trees at different stand ages in rotation. Total land under Pinus species is 2548 ha covering about $70 \%$ of total land area. The average age of the whole estate as at September 2010 was 10.9 years. The Pinus species planted in the estate include P. elliottii (Slash Pine), P. taeda (Loblolly Pine), P. patula (Patula Pine), and P. tecunumanii (Tecun Uman Pine). P. patula, Schiede \& Deppe is the most dominant comprising more than $95 \%$ of the planted area. The compartments are established at 1100 stems per ha (s.p.h.a), thinned twice at 4 years to 650 s.p.h.a and at 12 years to 400 s.p.h.a before clear felling at 25 years. Cleaning or weeding is carried out twice in the first year, and one slash weeding in the second year (WATCO, 2010). Before the establishment of pines, native forests were cleared and burnt before marking and pitting for initial planting.

\subsection{Experimental design and data collection}

Plots were selected to represent pine age classes of $1,10,20,25$, and 30 years. Also, a moist broad leaf forest and a miombo woodland were included in the study to represent soils prior to clearing for pine planation. The miombo woodland is frequently accessed by neighbouring communities whereas the moist forest is less accessible. Among the pine stands, two stands were selected from different management blocks and in each stand, three sampling plots ( 0.04 ha each) were randomly selected. All pine stands were in their first rotation except the 1 year old which is now entering a second rotation. At each sampling plot, geo-location and altitude were recorded using a Garmin GPS device. Slope was recorded using a Clinometer. Aspect, undergrowth species and, ground cover were observed and noted. At each sampling point tree measurements, forest floor and soil samples were collected as described below.

At each plot centre, forest floor was sampled from inside a metal ring of $30 \mathrm{~cm}$ diameter. The forest floor was stratified into three layers: (1) litter layer (L) - consisting of fresh and recently fallen, non-decomposed material. The material is identifiable by the naked eye as plant residues. This layer usually contains less than $10 \%$ fine organic matter, (2) fragmented layer $(F)$ - organic material is fragmented and partly decomposed with plant residues being macroscopically recognizable and $(3)$ the humus layer $(\mathrm{H})$ - consists of decomposed organic matter, originating from litter fall from decades ago and root turnover. The materials are decomposed and their origins are no longer distinct from each other with more than 70\% being fine organic matter (Currie, 1999; Schulp et al., 2008; Keith et al., 2010).

Next, pits were dug to a depth of $60 \mathrm{~cm}$. At each depth increment, i.e. $0-10,10-30$ and $30-60 \mathrm{~cm}$, a composited $300-400 \mathrm{~g}$ bulk sample was taken by sampling the four sides of the pit. In addition, bulk density (BD) samples were taken using a $100 \mathrm{~cm}^{3}$ metal ring sampler at each depth increment centre. All soil samples were put into labelled air tight plastic bags and stored in a cool dry place. A total of 108 bulk soil samples and 108 bulk density samples were collected ( 5 pine stand ages $\times 2$ stands each $\times 3$ pits $\times 3$ depths plus 2 natural forests $\times 3$ pits each $\times 3$ depths). At each sampling point, a $1 \mathrm{~m}^{2} \times 1 \mathrm{~m}^{2}$ area was cleared to trap litter to assess annual litter fall in each age class.

Diameter at breast height (DBH, at $1.3 \mathrm{~m}$ ) and tree height were recorded for every tree within a radius of $11.28 \mathrm{~m}$. Tree height was measured for every third tree using a Suunto hypsometer. Stand stem volume $(V)$ for pine stands was calculated from stand basal area $\left(\mathrm{BA}=\pi D^{2} / 4\right)$ and mean tree height $(H)$ using the standard biometric equation:

$V=\mathrm{BA} \times H \times f$ 
which includes a standard stem form factor $(f)$ of 0.4 (Cannell, 1984). Basic wood density was obtained from Muneri and Balodis (1998) and a biomass expansion factor of 1.3 (FAO, 1997) were used to convert stem wood volume to biomass.

For the natural forests, generalised allometric equations intended for all species types in broad forest types and ecological zones were used to determine the forest C stocks using Eq. (2) (Brown et al., 1989) and Eq. (3) (Malimbwi et al., 1994) and an average of the two was used.

$$
34.47-8.067 \mathrm{DBH}+0.659 \mathrm{DBH}^{2}
$$

$\operatorname{Exp} 2.516 \ln (\mathrm{DBH})-2.642$

The equations use DBH to explain variation in aboveground forest $C$ stocks. Based on this we assumed that we will be able to generate reliable estimates of $C$ stocks based on trees with DBH $\geqslant 5$ $\mathrm{cm}$ in the natural forests without using species-specific allometric equations. The mean of two equations was taken as the biomass of each forest. Carbon stocks were calculated using a factor of 0.5 to obtain C stocks (as $50 \%$ of biomass is C).

\subsection{Laboratory analysis}

The field moisture content was determined gravimetrically by drying each bulk density sample in an oven at $105^{\circ} \mathrm{C}$ for $48 \mathrm{~h}$. Samples were weighed before and after drying and percentage field moisture and the BD grams ( $g$ ) of dry soil $/ 100 \mathrm{~cm}^{3}$ (volume of ring) were calculated. Soil $\mathrm{pH}$ was measured with a $\mathrm{pH}$ meter (Orion $701 \mathrm{~A}$ ) in a $1 \mathrm{M} \mathrm{KCl}$ solution suspension for each stand age and soil depth.

The bulk soil samples (BS) were passed through a $2.00 \mathrm{~mm}$ Retsch sieve after which $>2.00 \mathrm{~mm}$ particles were discarded. These particles included roots, large charcoal and rock material in most cases. A sample of $10 \mathrm{~g}$ of the dry soil sieved to $2.00 \mathrm{~mm}$ (BS) was put into a moisture free hard graphite container with a metal ball inside. The container was put on a Restsch mill and span at $85 \mathrm{rpm}$ for $5 \mathrm{~min}$. The resultant ground soil was sealed in a glass container. A 15-20 mg subsample of ground soil was weighed into a tarred $5 \times 5 \mathrm{~mm}$ Aluminium foil, sealed and analysed for total $\mathrm{C}$ and $\mathrm{N}$ by dry combustion in a EA1108 CHN Elemental analyser (Fisons Instruments). The total $\mathrm{C}$ in forest floor and SOM were used to obtain total organic carbon (TOC, $\mathrm{kg} \mathrm{m}^{-2}$ of $\mathrm{C}$ ) for each age class thus quantifying the relative contribution of each forest or plantation age. Forest floor $C$ stocks were calculated by multiplying $C$ concentration with sample mass and dividing this by the area of the sample. Soil organic C stocks were calculated by multiplying $\mathrm{C}$ concentration with bulk density and thickness of the soil layer with a correction for stone content following equations:

Carbon stock $=d \times \mathrm{BD} \times \mathrm{SOC} \times \mathrm{CF}_{\mathrm{st}}$

where Carbon stock $\left(\mathrm{kg} / \mathrm{m}^{2}\right), d=$ depth of horizon $(\mathrm{m}), \mathrm{BD}=$ bulk density $\left(\mathrm{kg} / \mathrm{m}^{3}\right)$ of the soil layer. SOC $=$ SOC concentration expressed as weight based percentage and $\mathrm{CF}_{\mathrm{st}}=$ correction factor for stone and gravel content:

$\mathrm{CF}_{\text {st }}=1-(\%$ stone $+\%$ gravel $) / 100$

\subsection{Soil organic matter fractions and characterisation}

Soil Organic Matter fractions were obtained following the method by Golchin et al. (1994b) but as described by Roscoe et al. (2000) with three states of physical protection for soil organic C: free light (fLF) (non-protected and extractable without sonication), occluded (oLF) (extractable by sonication) and protected (MaHF) (remained in the residue after sonication). Sodium
Polytungstate (SPT) solution with a density of $1.6 \mathrm{~g} \mathrm{~cm}^{-3}$ was used to separate the fractions at $4500 \mathrm{rpm}$ in a Mistral 6000 centrifuge. Ultrasonic energy at $90 \%, 30 \mathrm{~W}$ output for $5 \mathrm{~min}$ from a Vibracell (Sonic Materials) was applied to the sample after removing the first fraction, to separate the occluded fraction from the mineralised fraction. The free and occluded fractions were extracted by vacuum filtration, filtering through a Whatman $0.5 \mu \mathrm{m}$ glass fibre filter, using a vacuum filtering unit, decanted into a tarred beaker, washed with distilled water to remove excess SPT and dried at $40{ }^{\circ} \mathrm{C}$. The mineralised fraction was obtained by totalling the dry weights of the first two fractions and subtracting from $10.0 \mathrm{~g}$ which was the original weight of the soil sample. The obtained fractions were prepared and analysed for total $\mathrm{C}$ and $\mathrm{N}$ by dry combustion.

\subsection{Statistical and data analysis}

Data was analysed after testing for normality (KolmogrovSmirnov test) and homogeneity of variance (Levene's test). One way analyses of variance (ANOVA) in SPSS v.18 (SPSS Inc., Chicago, Illinois, USA) was used to assess the effects of age and depth on the forest floor ( $\mathrm{C}$ and $\mathrm{N}$ ), soil $\mathrm{pH}$, bulk density, whole soil $\mathrm{C}$ and $\mathrm{N}$ contents, soil organic $\mathrm{C}$ and $\mathrm{N}$ storage in density fractions and the associated C:N ratios. A separate analysis was done to assess differences between older pine age classes (25 and 30 years) and natural forests. Tukey's HSD tests were used to test significant effects at $p \leqslant 0.05$.

\section{Results}

\subsection{Forest floor $C$ and $N$ distribution}

The $\mathrm{L}, \mathrm{F}$ and $\mathrm{H}$ layers of the forest floor were distinct in all natural and plantation forests except the 1 year old plantation stands which had no L layer but had abundant ground cover dominated by pioneer species. Mean thickness of the three forest floor layers (L, F, $\mathrm{H})$ for $1,10,20,25$ and 30 years were $0.0,3.0,3.5 \mathrm{~cm} ; 1.3,2.5$, $3.7 \mathrm{~cm} ; 1.3,1.9,2.9 \mathrm{~cm} ; 2.2,3.0,1.8 \mathrm{~cm}$ and $1.7,5.2,3.2 \mathrm{~cm}$ respectively. In the MW each layer was $0.5 \mathrm{~cm}$ whereas in the MF thickness of $\mathrm{L}, \mathrm{F}$ and $\mathrm{H}$ layers was $0.5,1.0$ and $1.0 \mathrm{~cm}$ respectively (Fig. 2).

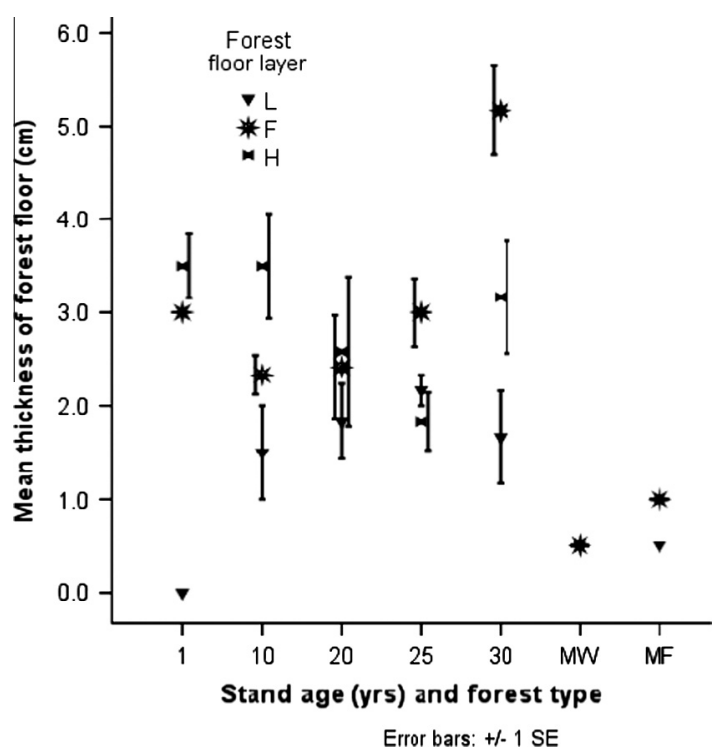

Fig. 2. Depth of forest floor litter $(\mathrm{cm})$ as a function of stand age and forest type. 

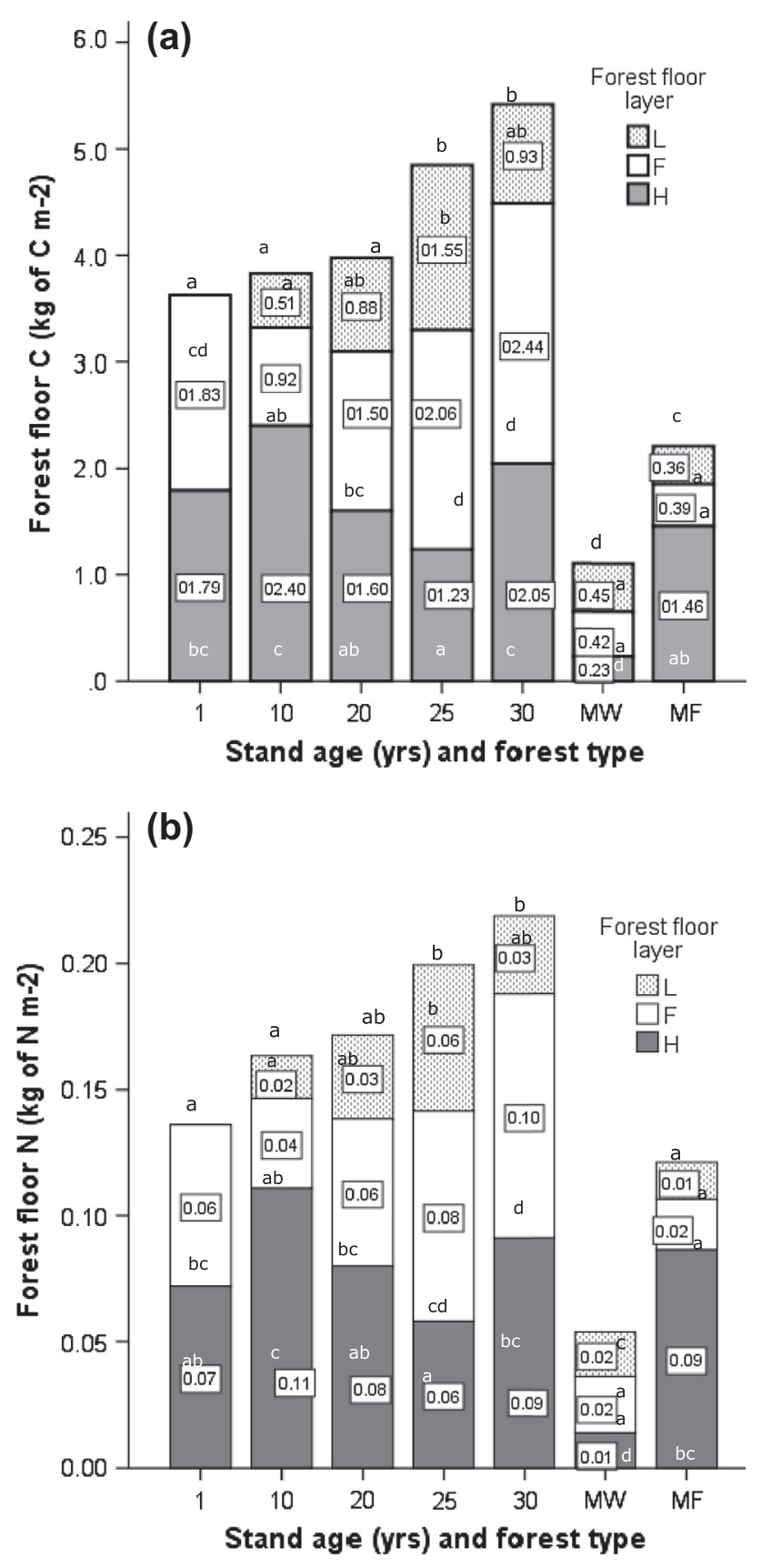

Fig. 3. The partitioning of (a) organic carbon and (b) organic nitrogen in forest floor of plantations $(1,10,25,30$ years), miombo woodlands (MW) and moist forests (MF). Different letters show significant differences in each stand and forest floor layers at $p \leqslant 0.05$.

Among the pine stands, total forest floor $\mathrm{C}$ was lowest in the 1 year old and highest in the 30 year old. All pine stands had significantly higher total forest floor $C$ than natural forests except the 1 year old which had total $\mathrm{N}$ stocks statistically similar to MF (Fig. 3). The amount of $\mathrm{C}$ and $\mathrm{N}$ in the forest floor was highest at 30 years $\left(5.4 \mathrm{~kg}\right.$ of $\mathrm{C} \mathrm{m}^{-2} 0.22 \mathrm{~kg}$ of $\mathrm{N} \mathrm{m}^{-2}$ ). Miombo woodlands had significantly low $(p<0.01) \mathrm{C}$ and $\mathrm{N}$ stocks in all three forest floor layers with $1.1 \mathrm{~kg} \mathrm{~m}^{-2}$ of $\mathrm{C}$ and $0.05 \mathrm{~kg} \mathrm{~m}^{-2}$ of $\mathrm{N}$ while the moist forest had $2.2 \mathrm{~kg}$ of $\mathrm{C} \mathrm{m}^{-2}$ and $0.12 \mathrm{~kg} \mathrm{~N} \mathrm{~m}^{-2}$. Despite the absence of the L layer in the one year old stand, there were no significant differences in cumulative forest floor $\mathrm{C}$ and $\mathrm{N}$ with the 10 and 20 year old stands.

Among the Pinus stands the $\mathrm{C}$ in the L layer of forest floor increased under respectively the 10,20 and 25 year old stands and at 30 years it was lower than at 25 years. Nitrogen followed similar trends with a decrease after 25 years. The increase between 10 and 25 years old stands was supported by increasing mean annual litter fall of $0.304,0.741$ and $0.932 \mathrm{~kg} \mathrm{~m}^{-2}$ dry mass for 10,20 and 25 years respectively (Table 1 ). The mean annual litter fall of the 30 year stands was slightly higher with $0.989 \mathrm{~kg} \mathrm{~m}^{-2}$. The annual $C$ additions to the L layer were therefore, $0.15,0.37,0.47$ and $0.49 \mathrm{~g} \mathrm{C} \mathrm{m}^{-2} \mathrm{yr}^{-1}$ for the 10,2025 and 30 year old stands with significant differences $(p<0.001)$ between successive years before age 25 .

Carbon and $\mathrm{N}$ content of the $\mathrm{F}$ layer decreased significantly $(p=0.024)$ from 1 year to 10 years and then increased significantly in subsequent years from 10 to 20 years $(p=0.008)$ and from 20 to 30 years $(p=0.022)$ of stand age. The $\mathrm{L}$ and $\mathrm{F}$ layer $\mathrm{C}$ and $\mathrm{N}$ were significantly higher $(p<0.01)$ in pine stand ages of 20,25 and 30 years than natural forest. The 25 and 30 year old stands had significantly higher $(p<0.01) C$ in the $\mathrm{F}$ layer than the natural forests.

The $\mathrm{H}$ layer, $\mathrm{C}$ and $\mathrm{N}$ contents were significantly higher $(p=0.010)$ under the 10 year old stands $\left(2.4 \mathrm{~kg} \mathrm{~m}^{-2}\right.$ of $\mathrm{C}$ and $0.11 \mathrm{~kg} \mathrm{~m}^{-2}$ of $\mathrm{N}$ ) than the 1,20 and 25 year old pine stands. The $\mathrm{C}$ in $\mathrm{H}$ layer of the 10 year old and MF was significantly higher $(p<0.01)$ than in the $\mathrm{F}$ layer. The $\mathrm{C}: \mathrm{N}$ ratios of the plantation stands and the MF showed similar trends with $\mathrm{C}: \mathrm{N}$ ratio decreasing from $\mathrm{L}$ to $\mathrm{F}$ to $\mathrm{H}$ whereas, in $\mathrm{MW}$ the $\mathrm{H}$ layer $\mathrm{C}: \mathrm{N}$ ratio was higher than the F layer (Table 2).

\subsection{Forest stand and soil characteristics}

Generally moist forests had significantly higher moisture content than the rest followed by the 1 year old pine stand (Table 1 ). Bulk density in MF was significantly higher than the 25 year old stand but significantly lower than all stands except the 10 year old. Among the pines, the 25 year old stand had significantly lower bulk density than all. Depth had no significant effect on soil $\mathrm{pH}$ (Table 3 ) and therefore only mean $\mathrm{pH}$ is recorded (Table 1) and it ranged from 4.2 to 5.1 with the MF having significantly higher $(p<0.01) \mathrm{pH}$ than all stands. The 25 year old stands had significantly lower $\mathrm{pH}$ than MW, 1, 10, 20 and 30 year old stands and MF.

Mean diameter at breast height ( $\mathrm{dbh})$, height, basal area and stand volume increased with increased stand age having a higher rate of increase from 1 to 10 and 20 years but increased at a decreasing rate from 25 years to 30 years (Table 1 ). Biomass $C$ was $0.02,23.0,33.8,57.1$ and $62.6 \mathrm{Mg} \mathrm{C}^{-1}$ for the $1,10,20,25$ and 30 year old stands respectively. In MW and MF the biomass C stocks were 11 and $103 \mathrm{Mg} \mathrm{ha}^{-1}$ respectively.

The cumulative total soil organic $C$ and $N$ stocks of $0-60 \mathrm{~cm}$ depth were largest under moist forest $\left(18.3 \mathrm{~kg} \mathrm{C} \mathrm{m}^{-2}\right)$ and lowest in MW ( $8.5 \mathrm{~kg} \mathrm{C} \mathrm{m}^{-2}$ ) (Table 4). Among the plantation stands, highest stocks were found under 10 -year old stands $\left(13.7 \mathrm{~kg} \mathrm{C} \mathrm{m}^{-2}\right)$ and lowest in the one year old stands $\left(9.9 \mathrm{~kg} \mathrm{C} \mathrm{m}^{-2}\right)$. Among the pines there was an increase in $\mathrm{C}$ and $\mathrm{N}$ from 1 to 10 years followed by a decrease at 20 years after which there was an increase at a decreasing rate (see Table 4).

The concentration of $\mathrm{C}$ and $\mathrm{N}$ was significantly different $(p<0.01)$ (Table 3$)$ between the three soil layers with highest $C$ percentages in the $0-10 \mathrm{~cm}$ depth except for the MW. At the 0 $10 \mathrm{~cm}$ depth increment, soil $\mathrm{C}$ and $\mathrm{N}$ concentration were lowest under MW and highest under MF (Fig. 4). Soil C concentration decreased for each stand age and natural forest with increasing soil depth from a mean of $36.9( \pm 0.5) \mathrm{g} \mathrm{C} \mathrm{kg}^{-1}$ at $0-10 \mathrm{~cm}$ to about $19.4 \mathrm{~g} \mathrm{~kg}^{-1}( \pm 0.5)$ at $30-60 \mathrm{~cm}$ depth although there were deviations in the MW. Nitrogen followed similar trends from $2.1 \mathrm{~g} \mathrm{C} \mathrm{kg}^{-1}( \pm 0.1)$ at $0-10 \mathrm{~cm}$ to $1.3 \mathrm{~g} \mathrm{C} \mathrm{kg}^{-1}( \pm 0.1)$ at $30-60 \mathrm{~cm}$.

The C: $\mathrm{N}$ ratios for whole soil increased with stand age from 10 years to 25 years and decreased again at 30 years. Depth distribution of mineral soil $\mathrm{C}: \mathrm{N}$ ratios decreased with increasing depth 
Table 1

Mean stand characteristics of Pinus patula stands of different ages and natural forests.

\begin{tabular}{|c|c|c|c|c|c|c|c|}
\hline Stand characteristics & 1 year & 10 years & 20 years & 25 years & 30 years & Miombo woodland & Moist forest \\
\hline Elevation (m) & 1864 & 1895 & 1808 & 1875 & 1897 & 1512 & 1871 \\
\hline Site Index & 20 & 26 & 26 & 24 & 26 & na & na \\
\hline Stocking (SPH) & $1100(0)$ & $650(0)$ & $395(2)$ & $397(2)$ & $398(1)$ & $308(15)$ & $712(21)$ \\
\hline Mean dbh $(\mathrm{cm})$ & nd & $23.1(0.2)$ & $32.1(0.6)$ & $36.7(0.5)$ & $38.1(0.1)$ & $9.2(2.5)$ & $29.6(5.1)$ \\
\hline Mean Ht (m) & $0.74(0.1)$ & $18.3(0.2)$ & $22.6(1.0)$ & $29.4(0.5)$ & $29.9(0.9)$ & $6.3(2.2)$ & $14.9(4.2)$ \\
\hline $\mathrm{BA}\left(\mathrm{m}^{2} \mathrm{ha}^{-1}\right)$ & $0.45(0.30)$ & $27.2(0.5)$ & $32.4(1.2)$ & $42.1(1.1)$ & $45.4(0.4)$ & $8.2(3.3)$ & $70.93(5.1)$ \\
\hline Volume ( $\left.\mathrm{m}^{3} \mathrm{ha}^{-1}\right)$ & $0.13(0.07)$ & $199.3(4.9)$ & $292.8(18.3)$ & 494.1(19.2) & $543.3(19.1)$ & nd & nd \\
\hline Litter fall $\left(\mathrm{kg} \mathrm{m}^{-2} \mathrm{yr}^{-1}\right)$ & nd & 0.304 & 0.741 & 0.932 & 0.989 & nd & nd \\
\hline Biomass C $\left(\mathrm{Mg} \mathrm{ha}^{-1}\right)$ & $0.02(0.01)$ & $23.0(0.6)^{\mathrm{ab}}$ & $33.8(2.1)^{b}$ & $57.1(2.2)^{\mathrm{c}}$ & $62.8(2.2)^{\mathrm{c}}$ & $10.7(3.0)^{\mathrm{a}}$ & $103.1(11.6)^{d}$ \\
\hline
\end{tabular}

$\mathrm{nd}=$ not determined, $\mathrm{SPH}=$ Stems per hectare, $\mathrm{BA}=$ basal area, $\mathrm{Ht}=$ height, $\mathrm{dbh}=$ diameter at breast height $(1.3 \mathrm{~m}$ above ground $)$.

Table 2

C:N ratios of three forest floor litter layers in pine stand ages and natural forests (MW and MF) (stand mean \pm S.D).

\begin{tabular}{|c|c|c|c|c|c|c|c|}
\hline \multirow[t]{2}{*}{ Litter layer } & \multicolumn{7}{|l|}{ Stand } \\
\hline & 1 & 10 & 20 & 25 & 30 & MW & MF \\
\hline $\mathrm{L}$ & - & $26(2)^{a b}$ & $29(4)^{\mathrm{bc}}$ & $26(1)^{a b}$ & $31(2)^{c}$ & $23(2)^{a}$ & $26(1)^{a b}$ \\
\hline $\mathrm{F}$ & $31(3)^{a}$ & $23(1)^{b c}$ & $25(2)^{c}$ & $26(2)^{c}$ & $24(2)^{c}$ & $21(4)^{b}$ & $20(1)^{b}$ \\
\hline $\mathrm{H}$ & $26(4)^{a}$ & $22(3)^{b}$ & $20(3)^{b}$ & $21(1)^{b}$ & $23(3)^{\mathrm{ab}}$ & $23(1)^{a b}$ & $16(1)^{c}$ \\
\hline Overall mean & $28(4)^{a}$ & $26(4)^{\mathrm{ab}}$ & $24(5)^{\mathrm{b}}$ & $24(3)^{b}$ & $26(4)^{a b}$ & $20(4)^{c}$ & $20(3)^{c}$ \\
\hline
\end{tabular}

Means followed by different superscripts in a row represent significant difference at $p<0.05$. Tukey's HSD.

Table 3

Results of the ANOVA on effects of forest stand age and soil depth on soil pH, soil organic carbon and nitrogen in bulk soil and density fraction.

\begin{tabular}{|c|c|c|c|c|c|c|c|}
\hline \multirow[t]{2}{*}{ Characteristic } & \multicolumn{2}{|l|}{ Age } & \multicolumn{2}{|l|}{ Depth } & \multicolumn{2}{|c|}{ Age * Depth } & \multirow[t]{2}{*}{$R^{2}$} \\
\hline & $F$ value & $P$ value & $F$ value & $P$ value & $F$ value & $P$ value & \\
\hline Soil pH & 25.70 & $<0.001$ & 0.393 & $<0.676$ & 0.627 & 0.814 & 0.654 \\
\hline $\mathrm{SOC}\left(\mathrm{kg} \mathrm{m}^{-2}\right)$ & 22.22 & $<0.001$ & 271.57 & $<0.001$ & 22.98 & $<0.001$ & 0.945 \\
\hline TON $\left(\mathrm{kg} \mathrm{m}^{-2}\right)$ & 7.22 & $<0.001$ & 34.16 & $<0.001$ & 7.17 & $<0.001$ & 0.862 \\
\hline fLF C $\left(\mathrm{Mg} \mathrm{ha}^{-1}\right)$ & 7.37 & $<0.001$ & 17.63 & $<0.001$ & 0.71 & 0.680 & 0.484 \\
\hline fLF N (Mg ha $\left.{ }^{-1}\right)$ & 9.39 & $<0.001$ & 15.93 & $<0.001$ & 1.02 & 0.429 & 0.508 \\
\hline $\operatorname{oLF} C\left(\mathrm{Mg} \mathrm{ha}^{-1}\right)$ & 6.04 & $<0.001$ & 6.55 & 0.002 & 1.35 & 0.232 & 0.391 \\
\hline $\operatorname{oLF~N}\left(\mathrm{Mg} \mathrm{ha}^{-1}\right)$ & 5.42 & 0.001 & 6.60 & 0.002 & 1.27 & 0.270 & 0.375 \\
\hline MaHF C $\left(\mathrm{Mg} \mathrm{ha}^{-1}\right)$ & 18.15 & $<0.001$ & 191.47 & $<0.001$ & 21.33 & $<0.001$ & 0.942 \\
\hline MaHF N $\left(\mathrm{Mg} \mathrm{ha}^{-1}\right)$ & 5.32 & 0.008 & 24.32 & $<0.001$ & 6.92 & $<0.001$ & 0.855 \\
\hline $\mathrm{C}: \mathrm{N}$ whole soil & 5.14 & 0.001 & 19.76 & $<0.001$ & 4.36 & $<0.001$ & 0.559 \\
\hline$C: N$ fLF & 5.64 & 0.001 & 0.625 & 0.538 & 0.92 & 0.504 & 0.294 \\
\hline C:N oLF & 5.59 & 0.001 & 0.557 & 0.575 & 0.32 & 0.957 & 0.258 \\
\hline $\mathrm{C}: \mathrm{N}$ MaHF & 4.56 & 0.002 & 20.19 & 0.001 & 4.45 & $<0.001$ & 0.658 \\
\hline
\end{tabular}

$\mathrm{SOC}=$ soil organic carbon, $\mathrm{TON}=$ total organic nitrogen, $\mathrm{fLF}=$ free light fraction, $\mathrm{oLF}=$ occluded light fraction, MaHF $=$ mineral associated heavy fraction.

in all pine stands with increasing age to a maximum at 25 years after which it decreased at 30 years as a result of decreased $\mathrm{C}$ and increased $\mathrm{N}$ content (data not shown). Natural forests (MW and MF) showed no trend with depth having highest $\mathrm{C}: \mathrm{N}$ ratios in MF at $10-30 \mathrm{~cm}$.

\subsection{Carbon and nitrogen in density fractions}

The distribution of fLF C and N was significantly higher than oLF in all stands. Among the pines the fLF and oLF were highest at 10 years and 20 years respectively (Fig. $5 \mathrm{a}$ and $\mathrm{b}$ ). Carbon and $\mathrm{N}$ contents of soil fractions were in the order MaHF $>\mathrm{fLF}>\mathrm{oLF}$ in all forest types and ages at the three depths levels. The fLF C contributed between $8 \%$ and $13 \%$ to total organic $C$ whilst the oLF C contributed the least (1-7\%) and MaHF C the most (90-91\%) to total SOC. The amount of fLF and oLF C and N decreased with increasing soil depth. Nitrogen followed similar trends.

The C:N ratios of SOM fractions showed a difference between the light fractions and the mineral associated fraction. There was a general decrease in $\mathrm{C}: \mathrm{N}$ ratios in each age class and natural forest in the order; fLF > oLF > MaHF (Fig. 5c). The 25 year old stands had highest $\mathrm{C}: \mathrm{N}$ ratios while the 30 year old showed $\mathrm{MaHF}<\mathrm{fLF}<\mathrm{oLF}$.
Significant differences in oLF and MaHF C:N ratios were mostly between natural forests and older pine stands.

The amount of fLF and oLF C and N decreased with increasing soil depth. The 10 year old fLF $C$ was significantly higher than the 20 and 25 year old and the MW. Free light fraction N was significantly lower in the 20 year old stand than all except MW. Vertically there was no significant difference in fLF $C$ although there was a decrease with increasing depth in all stands. The fLF $\mathrm{N}$ at $0-$ $10 \mathrm{~cm}$ was significantly higher than the lower layers $(P<0.01)$ (Fig. 6).

The oLF C in the 25 year old stands was significantly lower than all stands. Natural forests (MW and MF) had significantly higher $\mathrm{C}$ than the 25 year old. Vertically, the oLF C at $30-60 \mathrm{~cm}$ was significantly lower than the $0-10 \mathrm{~cm}$ and $10-30 \mathrm{~cm}$ depths. The oLF $\mathrm{N}$ at $10-30$ was significantly lower than the $0-10 \mathrm{~cm}$ depth $(p=0.042)$.

Among the pine stands MaHF $C$ was significantly different between successive years being significantly lower than MF $(p<0.02)$ except the 10 year old stands. The 25 year old stand was not significantly different from the 20 and the 30 year old stands. The MaHF C content of the MW and MF was significantly 

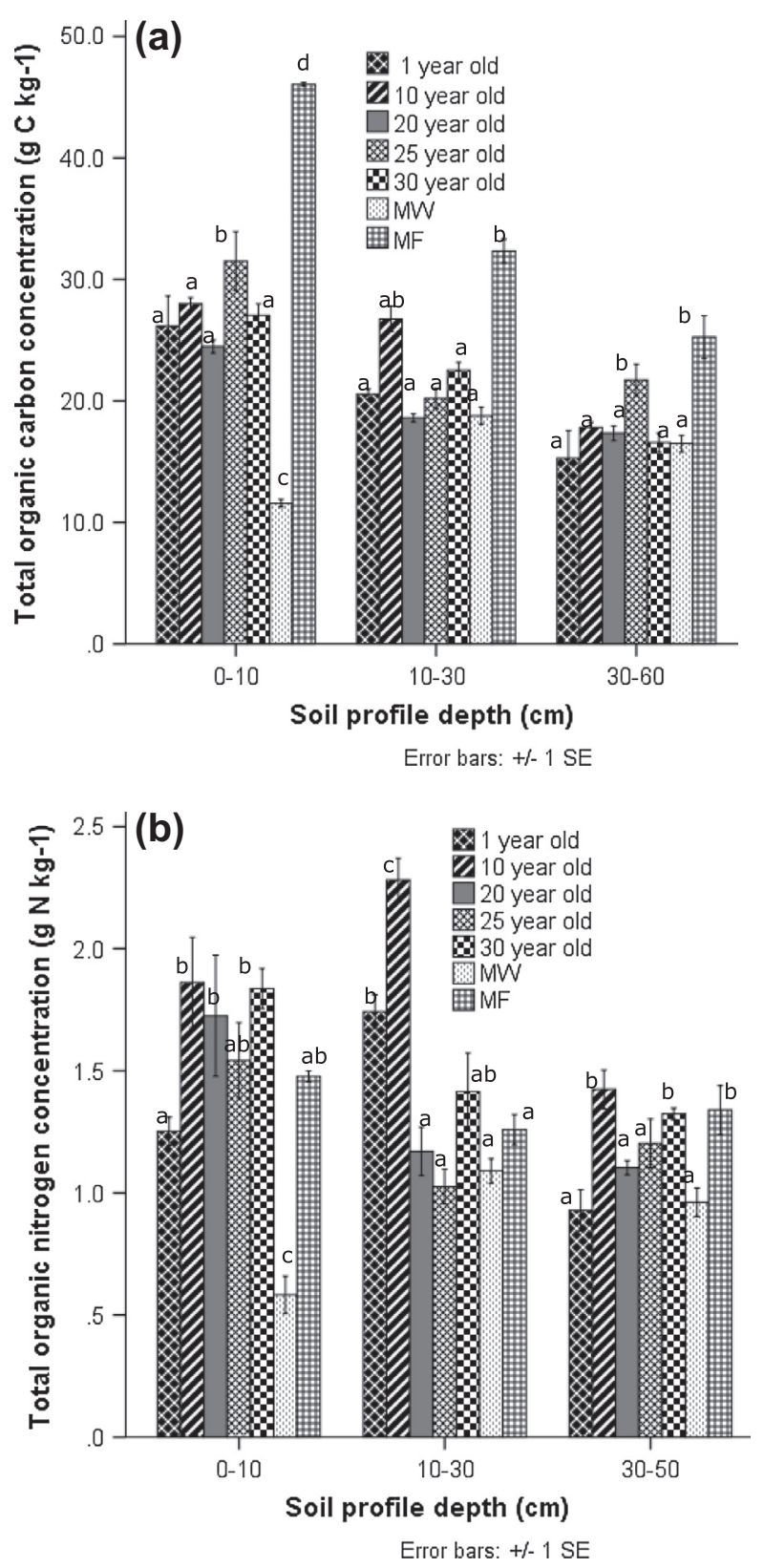

Fig. 4. Soil organic $C$ and $N$ concentration up to a depth of $60 \mathrm{~cm}$ in pine stands (1, $10,20,25$ and 30 years) and natural forests (MW and MF). Different letters show significant differences for each depth at $p \leqslant 0.05$. Error bars show standard error of the mean.

different from the pine stands being significantly lower in MW and higher in MF. Significant differences by depth were shown between all depths with the $0-10 \mathrm{~cm}$ layer being significantly higher than the $10-30 \mathrm{~cm}$ and $30-60 \mathrm{~cm}$ depths $(p<0.02)$. The $\mathrm{C}$ and $\mathrm{N}$ in MaHF decreased with increasing depth except MW.

Correlations between forest floor $C$ and $C$ in density fractions showed a stronger relationship (67\%) between forest floor and MaHF followed by fLF (60\%). There was also a positive correlation between fLF and MaHF C (64\%). The oLF had weak relationships with the other two fractions and with forest floor fractions.

\section{Discussion}

\subsection{Forest floor $C$ and $N$}

The thickness of forest floor layers in the 30 year old stand was significantly higher than all stands (Fig. 2). The thickness of the forest floor layers did not have corresponding effects on the amounts of carbon in pines. The MW had lowest forest floor thickness and soil $\mathrm{C}$ and $\mathrm{N}$ stocks. The importance of forest type and management in determining $\mathrm{C}$ and $\mathrm{N}$ stocks in forest ecosystems was demonstrated by the differences in $\mathrm{C}$ and $\mathrm{N}$ in $\mathrm{L}, \mathrm{F}$ and $\mathrm{H}$ forest floor layers in pine stands and natural forests. These differences in $\mathrm{C}$ and $\mathrm{N}$ stocks may in turn have an impact on mechanisms of nutrient cycling (Kim et al., 2010). In this ecosystem, fire was used as part of management tool to prepare the 1 year old sites and this had an effect on the amounts of litter thus impacting forest floor pools as demonstrated by the lack of the L layer in the 1 year old stands (Fig. 3). Czimczik et al. (2003) also attributed low forest floor litter dry masses to effects of fire while working in Scots pine forests. At year one, there was no $\mathrm{L}$ layer but the $\mathrm{F}$ and $\mathrm{H}$ layers were similar and higher than the 10 and 20 year olds. By the age of 10 , there was an increase in $\mathrm{H}$ layer and a decrease in $\mathrm{F}$ with additions onto the $\mathrm{L}$ layer. There is possibility that some of the F material was transformed into $\mathrm{H}$ while some the $\mathrm{H}$ material might have been incorporated into mineral soil by the age of 10 years and beyond.

The period shortly after establishing a new rotation by planting seedlings, shows higher decomposition than accumulation of organic material on forest floor. As the young trees grow older, a higher amount of biomass is accumulated leading to higher litter-fall. By the age of 10 , there was more $\mathrm{H}$ layer $\mathrm{C}$ and $\mathrm{N}$ from the decomposition of accumulated organic matter that survived the fires during land preparation coupled with the accumulation from decaying pioneer species. The net $\mathrm{C}$ input in the initial years is not only from litter fall, but also from residue decomposition after conversion and also decay of pioneer species including grass species which dominate the forest floor before canopy closure. The relationship between age and C conforms to the Covington's curve only for the L layer where the layer starts to develop with time up to a maximum level. Covington (1981) also found a general decrease in forest floor organic matter in the first 15 years after harvesting of Northern hardwoods. In a rotation, litter-fall becomes important for nutrient cycling in the forest-soil, being the largest inflow of $C$ and nutrients to the forest floor (Starr et al., 2005). After year 10 there was a reduction in $\mathrm{H}$ with increases in $\mathrm{F}$ and $\mathrm{L}$ layers.

At 20 years $\mathrm{L}, \mathrm{F}$ and $\mathrm{H}$ were not significantly different while at 25 more $\mathrm{L}$ had accumulated on the forest floor and part of $\mathrm{F}$ and $\mathrm{H}$ incorporated into the soil. There was a reduction of $\mathrm{H}$ layer and an increase in F and L layers. More mineralisation and increased breakdown of $\mathrm{L}$ to $\mathrm{F}$ constituents continued up to the age of 30 years with reduced quantities of fresh litter. This cycle substantiates the importance of the current 25 year rotation age of pines where thickness of the forest floor layers and subsequently the $C$ they contain are associated with an increase in stand age in pine tree forests (Dames et al., 1998; Bens et al., 2006; Matos et al., 2010; Penne et al., 2010; Shrestha and Chen, 2010). Pinus plantations are known to culminate in volume and biomass production at the age of 25 years which is much earlier than natural forests (Augustin et al., 2007). Although total C in forest floor increased between the 10 and 30 year old stands, our results suggests that forest floor $C$ increased at a decreasing rate beyond the age of 25 years. The results agree with the findings of Li et al. (2011) who found no further increase beyond the age of 35 years while working in Korean pine stands.

There was an decrease in C: $\mathrm{N}$ ratios in all except MW from the $\mathrm{L}$ to $\mathrm{F}$ to $\mathrm{H}$ layers (Table 2), suggesting an increase in humification 

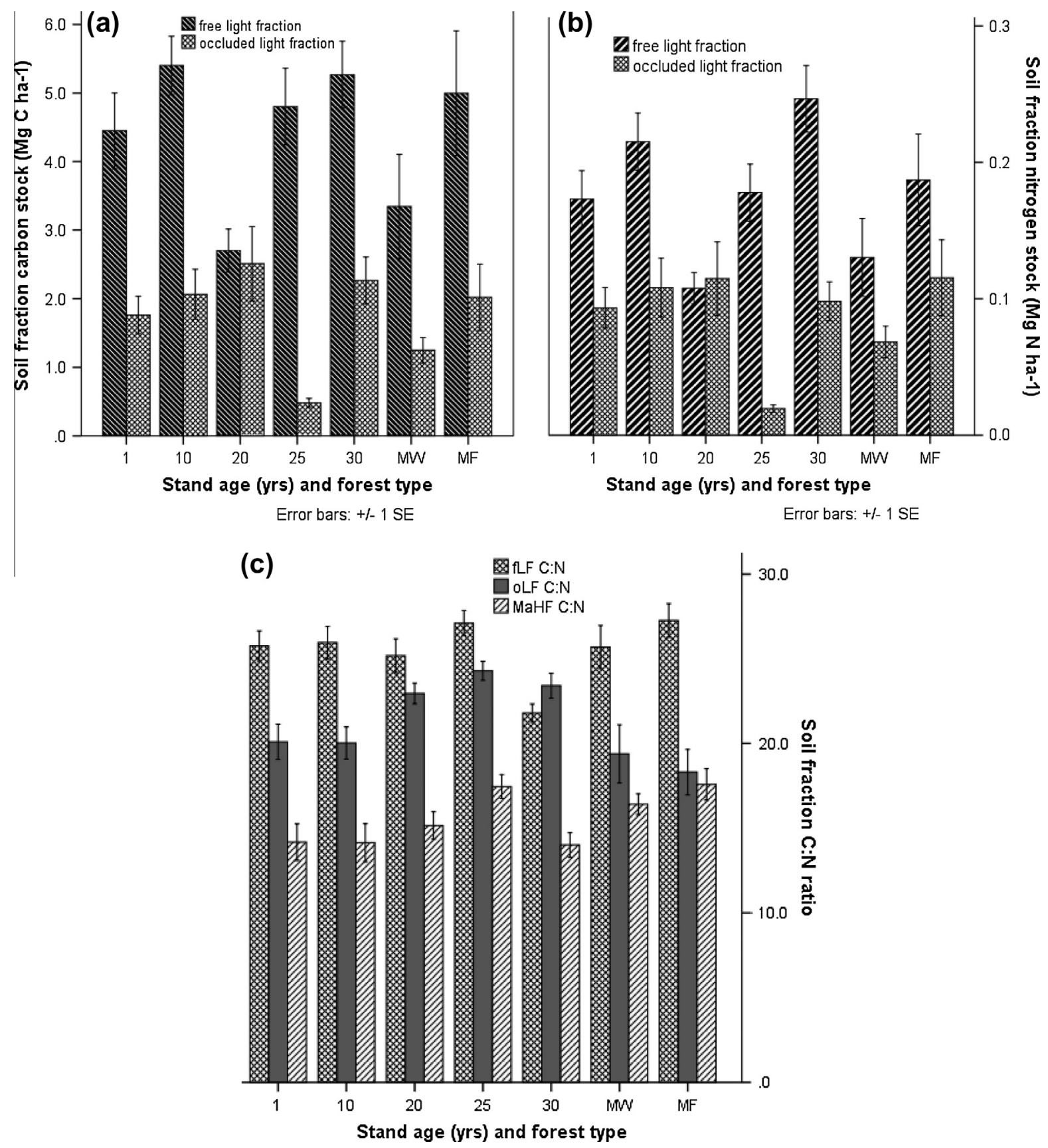

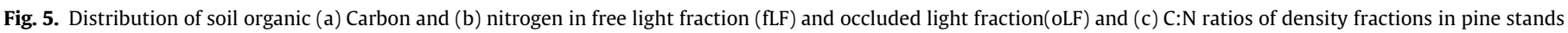
and natural forests. $\mathrm{MaHF}=$ mineral associated heavy fraction.

with depth. Although C:N ratios in forest floor and soil generally remain stable (Yang and Luo, 2011), there were significant differences between overall C: $\mathrm{N}$ ratio of the one year old stand and the 20 and 25 year old stands (Table 2). The C: $\mathrm{N}$ ratios of forest floor $\mathrm{F}$ and $\mathrm{H}$ layers were lower under MF than the other stands indication a better quality of $\mathrm{F}$ and $\mathrm{H}$ materials. Fine root decomposition can also add $C$ to these layers (Hoosbeek et al., 2011). The influence of fine roots and charcoal on C: $\mathrm{N}$ ratios is also reported by Golchin et al. (1994a). Burning causes short term increases in soil available $\mathrm{N}$ which results in a stimulation of growth of pioneer species in one year old stand. In addition fire reduces quality of the substrate resulting in larger C: $\mathrm{N}$ ratio in the one year old stand.

\subsection{Forest stand and soil characteristics}

Among the pines, the 1 year old stands had more moisture despite having less shade. The thick accumulation of $\mathrm{F}$ and $\mathrm{H}$ forest floor material after the process of burning for land preparation provided ground cover thus reducing soil and water loss (van Bodegom et al., 2008). In addition, one year old trees take up less water than trees of 10 or more years of age. Higher soil moisture content and temperature during the early years of the rotation accelerated litter decomposition and increased the transformation of $\mathrm{F}$ into $\mathrm{H}$ litter which was manifested in the 10 year old stands. This may also have caused an increase of dissolved organic carbon (DOC) production and leaching of the DOC into mineral soil, thus subsequently adding more $\mathrm{C}$ into the soil. 

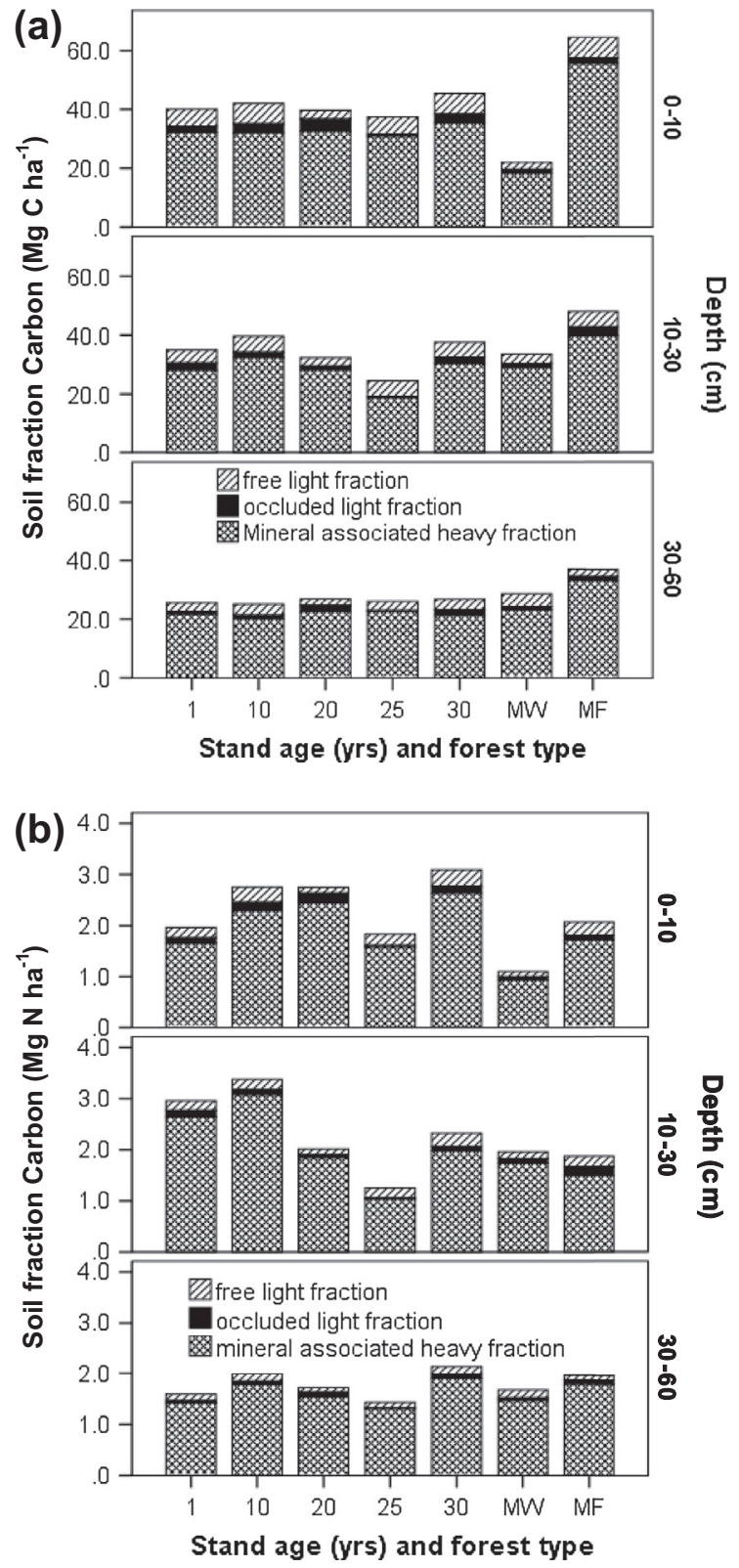

Fig. 6. Depth distribution of carbon and nitrogen in density fractions in pine stands of $1,10,20,25$ and 30 years and natural forests (MW and MF). fLF = free light fraction; $\mathrm{oLF}=$ occluded light fraction and $\mathrm{MaHF}=$ mineral associated heavy fraction.

There were significant differences in $\mathrm{pH}$ among pine ages which followed no trend with the MF having highest $\mathrm{pH}$ than all the other stands (Table 1). The $\mathrm{pH}$ was significantly lower in pine stands than MF thus supporting the idea of pines acidifying soils (Parfitt and Ross, 2011; Kundhlande et al., 2012). Liao et al. (2012) however, found no significant differences in $\mathrm{pH}$ of natural and planted forests while working on other coniferous species.

Bulk density in plantation stands was lower than MW but significantly higher than MF being significantly different between the one year old and the 25 year old stand (Table 1 ). There was no trend in bulk density with age although Liao et al. (2012) found significant increase in bulk density with age in plantation stands. In this study, storage of $C$ remained high in MF despite the low bulk density and was also lowest in MW despite having the highest bulk density. We therefore attribute $\mathrm{C}$ storage in the different stands with differences in C concentration (Fig. 4).

Total aboveground biomass $C$ increased from 1 to 25 years after which it increased at a decreasing rate, demonstrating a rapid increase from 1 year to the 10 year old stand, and from the 10 - to the 25-year old stand (Table 1). Carbon storage estimated for the MW in this study $\left(10.7 \mathrm{Mg} \mathrm{ha}^{-1}\right)$ is higher biomass $\mathrm{C}$ stocks of coastal miombo in Tanzania (Malimbwi et al., 1994) but lower than miombo woodlands in Mozambique (21.2 $\mathrm{Mg} \mathrm{ha}^{-1}$ ) and Tanzania (23.3 $\mathrm{Mg} \mathrm{ha}^{-1}$ ) (Shirima et al. (2011)). The estimated storage of C in $\mathrm{MF}\left(103 \mathrm{Mg} \mathrm{ha}^{-1}\right)$ is lower than estimates from tropical rainforests of Africa (202 $\mathrm{Mg} \mathrm{C} \mathrm{ha}^{-1}$ ) (Lewis et al., 2009).

The species diverse, natural moist forest which is assumed to be an old and more stable ecosystem contained more biomass and soil $\mathrm{C}$ and $\mathrm{N}$ compared to the homogenous 25 and 30 year old pine forests and the MW (Tables 1 and 4). Studies in Mozambique showed $7.6 \mathrm{~kg} \mathrm{C} \mathrm{m}^{-2}$ in MW soils (Ryan et al., 2011), a figure which is lower than the $C$ in the MW in this study area and within the range of other MW in Southern Africa (3-13.3 $\mathrm{kg} \mathrm{m}^{-2}$ ). The conversion from a moist forest to a plantation, can however result in depleted $\mathrm{C}$ and N stocks (Hudiburg et al., 2009; Gonzalez-Benecke et al., 2010; Wendling et al., 2010; Liao et al., 2012) whilst C benefits may be realised when MW is converted to pine plantations beyond 25 years. Similar results of differences between broad leaved forests and pine plantations were reported by Jandl et al. (2007) and Wendling et al. (2010), who showed the former ecosystems to contain more SOC than shallow rooted pine plantations. In addition, pine plantations have poorly developed rooting systems which make them less efficient at trapping nutrients when compared to natural moist forests (van Bodegom et al., 2008). Nevertheless, Brown et al. (1985) stated that plantations can sequester more $\mathrm{C}$ with time as they develop and grow into older age classes and thus, supports the results of this study.

A rotation has a set of programmed silvicultural operations such as thinning ( 4 years and 14 years) and pruning (3 years and 12 years) and weeding which can continually add $C$ inputs into forest floor and soil $\mathrm{C}$ pools and this could be the reason why the one year old stand was not severely depleted. Although the forest was under pines for 25 years, the SOC stocks were not restored to the levels of MF although part of the $\mathrm{C}$ is stored as root biomass. In addition, the rotation system contains charcoal produced during burning for land preparation causing redistribution of $\mathrm{C}$ and $\mathrm{N}$ at depths of $10-30 \mathrm{~cm}$ at 10 years and even deeper after several years. There were no significant differences between MW and the older age classes of Pinus stands of 20,25 and 30 years at a depth of 30-60 cm. The lower biomass $C$ in $\mathrm{MW}$ and at $0-10 \mathrm{~cm}$ and 20 $30 \mathrm{~cm}$ could be attributed to frequent disturbance as neighbouring communities utilise the woodland for timber and non-timber forest products and this results in a higher degradation pressure accompanied with lower C storage than their potential (Brown, 1997). This shows the importance of land use change in C storage.

A diverse undergrowth can produce litter exposed to decomposers following establishment of a new rotation and hence the 10 year old stand had the highest $C$ and $N$ concentrations at a time when all pioneer species are gone which could be attributed to incorporation of $\mathrm{F}$ and $\mathrm{H}$ material into mineral soil. This high accumulation of $C$ could be associated with litter input from the non- tree vegetation (Black et al., 2009). In this way the process of succession and decomposition of pioneer species enhanced more fine roots and litter in the upper soil thereby increasing $C$ concentrations in the early years of establishment (Hoosbeek et al., 2011). There was also an increases in C inputs into upper soil layers despite the burning for land preparation where fine roots are burnt and charcoal is added into the soil. Black et al. (2009) studied Picea sitchensis, Bong. Carr. and found highest sequestration rates at 10 years, which subsequently declined after canopy closure in old- 
Table 4

Depth distribution of bulk SOC and TON in Pinus patula stands of different ages and natural forests.

\begin{tabular}{|c|c|c|c|c|c|c|c|}
\hline Soils characteristics & 1 year & 10 years & 20 years & 25 years & 30 years & Miombo woodland & Moist forest \\
\hline Moisture (\%) & $12.5(0.3)^{\mathrm{a}}$ & $9.1(0.1)^{b}$ & $9.7(0.1)^{\mathrm{b}}$ & $11.1(0.1)^{\mathrm{ab}}$ & $9.2(0.0)^{\mathrm{b}}$ & $9.2(0.4)^{b}$ & $18.0(0.1)^{c}$ \\
\hline $\mathrm{BD}\left(\mathrm{g} \mathrm{cm}^{-3}\right)$ & $1.68(0.02)^{\mathrm{a}}$ & $1.54(0.01)^{\mathrm{ab}}$ & $1.69(0.01)^{\mathrm{a}}$ & $1.43(0.02)^{b}$ & $1.64(0.01)^{\mathrm{a}}$ & $1.93(0.04)^{\mathrm{c}}$ & $1.45(0.01)^{b}$ \\
\hline Mean pH & $4.5(0.6)^{\mathrm{a}}$ & $4.7(0.1)^{\mathrm{a}}$ & $4.6(0.0)^{\mathrm{a}}$ & $4.2(0.1)^{\mathrm{ab}}$ & $4.5(0.1)^{\mathrm{a}}$ & $4.6(0.1)^{\mathrm{ab}}$ & $5.1(0.1)^{\mathrm{c}}$ \\
\hline \multicolumn{8}{|l|}{ Bulk soil C $\left(\mathrm{kg} \mathrm{m}^{-2}\right)$} \\
\hline $0-10 \mathrm{~cm}$ & $4.0(1.9)$ & $7.2(1.9)$ & $4.3(1.8)$ & $6.6(1.9)$ & $4.6(1.9)$ & $2.2(0.3)$ & $8.4(0.3)$ \\
\hline $10-30 \mathrm{~cm}$ & $3.5(1.9)$ & $4.0(1.6)$ & $3.2(0.18)$ & $2.5(1.9)$ & $3.8(1.9)$ & $3.4(0.2)$ & $5.8(0.2)$ \\
\hline $30-60 \mathrm{~cm}$ & $2.4(1.9)$ & $2.5(0.19)$ & $2.6(0.19)$ & $3.0(1.9)$ & $2.8(1.9)$ & $2.9(0.3)$ & $4.1(0.3)$ \\
\hline Total $(0-60 \mathrm{~cm})$ & $9.9(2.0)^{\mathrm{a}}$ & $13.7(1.2)^{b}$ & $10.1(0.1)^{\mathrm{ab}}$ & $12.1(1.1)^{\mathrm{b}}$ & $11.2(2.1)^{\mathrm{ab}}$ & $8.5(0.2)^{\mathrm{a}}$ & $18.3(1.2)^{\mathrm{c}}$ \\
\hline \multicolumn{8}{|l|}{ Bulk soil $N\left(\mathrm{~kg} \mathrm{~m}^{-2}\right)$} \\
\hline $0-10 \mathrm{~cm}$ & $0.20(0.02)$ & $0.36(0.02$ & $0.28(0.02$ & $0.35(0.02$ & $0.31(0.02$ & $0.13(0.03)$ & $0.53(0.02)$ \\
\hline $10-30 \mathrm{~cm}$ & $0.30(0.02$ & $0.32(0.02$ & $0.21(0.02$ & $0.14(0.02$ & $0.23(0.02$ & $0.20(0.03)$ & $0.33(0.03)$ \\
\hline $30-60 \mathrm{~cm}$ & $0.18(0.02$ & $0.21(0.02$ & $0.17(0.02$ & $0.18(0.02$ & $0.21(0.02$ & $0.17(0.03)$ & $0.20(0.03)$ \\
\hline Total $(0-60 \mathrm{~cm})$ & $0.66(0.01)^{b}$ & $0.85(0.01)^{b}$ & $0.66(0.01)^{a}$ & $0.67(0.01)^{a}$ & $0.22(0.01)^{\mathrm{ab}}$ & $0.22(0.02)^{a}$ & $0.25(0.02)^{\mathrm{ab}}$ \\
\hline $\mathrm{C}: \mathrm{N}$ ratio & $15(2)$ & $16(1)$ & $15(2)$ & $19(3)$ & $17(2)$ & $13(3)^{\mathrm{b}}$ & $24(4)^{c}$ \\
\hline
\end{tabular}

Different superscripts show significant difference at $p<0.05$. Tukey's HSD test. Figures in parenthesis show standard error of the mean.

er and thinned stands. There could also be other factors affecting $C$ and $\mathrm{N}$ dynamics including management activities such as pruning, thinning and other tending operations. In this study, the $\mathrm{C}$ and $\mathrm{N}$ were lowest soon after establishment but recovered rapidly by the age of 10 years, after which it declined possibly as a result of silvicultural operations such as thinning and pruning after which was recovery again by the age of 25 years. This shows that plantations can be used efficiently to create $C$ sinks because of the rapid growth rates soon after establishment and additions that come as the trees develop and grow into older age classes.

There was a small decrease in soil $\mathrm{C}: \mathrm{N}$ ratios before 10 years of stand development which is similar to the findings of Georgiadis (2011) who was working in temperate forests. This was supported by Olsson et al. (1996) who showed decreased C:N ratios during the initial 8-15 years of stand development. The highest $\mathrm{C}: \mathrm{N}$ ratio was in the 25 year old stands showing a limitation in the rate of decomposition which may be affected by the low $\mathrm{pH}$ values.

\subsection{Carbon and nitrogen in soil organic matter fractions}

There were no outstanding differences in mass distribution of the MaHF among stand ages and forest types. Differences were distinct in fLF and oLF showing highest proportion of fLF in MF whilst oLF was not outstanding but only lowest at 25 years (Fig. 5). The pattern of $\mathrm{C}$ and $\mathrm{N}$ storage in SOM fractions was consistent with bulk soil C. Carbon and $\mathrm{N}$ in different forests showed greater quantities of fLF C in MF due to incorporation of above ground litter into the mineral soil by bioturbation. Under pine stands bioturbation is negligible leaving the above ground litter on top of the mineral soil. Carbon and $\mathrm{N}$ in fLF under pines is mostly the result of root turnover.

The fLF C showed a decrease with increasing depth (Fig. 6) in all pine stand ages except the 1 year old and natural forests which is in line with the observed root distribution. Tropical soils, such as the ones in the study area, are reported to contain high fLF C in the top $30 \mathrm{~cm}$ of the soil (Trumbore et al., 1996) decreasing with depth due to less inputs (litter and fine roots become fewer with increase in depth). However, this trend was not evident in the one year old stand, MW and MF. This deviation could be attributed to the influence of fire before land preparation and additions through root decomposition in the soil layers after subsequent harvesting in pine stands and root decay after land clearing. A combination of the effects of preparatory fire, management (harvest removal and pruning) and decomposition could result in addition of more free light organic matter to deeper soil layers without any pattern.
Total $\mathrm{C}$ and $\mathrm{N}$ in soil and in occluded and mineral associated fractions generally decreased with increase in depth in all forest types and ages which is similar to other studies (Tan et al., 2007; Usuga et al., 2010; Jiménez et al., 2011). Age of a forest plays an important role in determining SOC quantities as shown by significant differences in SOC fractions. The MaHF is important for containing recalcitrant $\mathrm{C}$ and thus contributes more to the long term stabilised SOC pool (Tan et al., 2007). Increasing stable C with successive rotations were noted by Zhang et al. (2009).

The $\mathrm{C}: \mathrm{N}$ ratios among the density fractions were different between the light fractions and the mineral associated fractions. A wider variation of $\mathrm{C}: \mathrm{N}$ ratios among density fractions were also shown by Golchin et al. (1994a). The observed decrease of C:N ratios with increasing SOC stabilisation, except for MW where anthropogenic effects may be dominant, is due to increased humification of SOM and the accumulation of large N-rich organic molecules originating from microbial biomass (Chan et al., 2008). Differences between C:N ratios of fLF, oLF and MaHF are probably due to differences in decomposition states were oLF is slightly more decomposed while MaHF is more advanced (Hassink, 1995).

\section{Conclusion}

We investigated the $C$ storage potential of a Pinus patula age sequence $(1,10,20,25$ and 30 years) and two natural forests. Cumulative $\mathrm{C}$ and $\mathrm{N}$ storage in stem biomass, forest floor and soil increased with stand age in pine stands. Although we may not have a perfect reference forest, assumption of stable equilibrium condition and potential $C$ storage can be assessed using existing forest fragments (MF and MW). In this regard the conversion from a moist forest to a plantation forest, results in depletion of $\mathrm{C}$ and $\mathrm{N}$ stocks but conversion of a miombo woodland to a pine plantation can be beneficial in the long run. Forest floor $\mathrm{C}$ and $\mathrm{N}$ peaked at 30 years and this may be related to additions from fine root biomass and litter fall. Stem biomass increased from 1 to 10 years and from 10 to 25 years and increased at a decreasing rate thereafter. As stem biomass and forest floor $C$ increased at 30 years, SOC decreased. Pine plantations store significantly more $\mathrm{C}$ and $\mathrm{N}$ in the forest floor than natural forests. Carbon in the forest floor decreased from $\mathrm{L}$ to $\mathrm{F}$ to $\mathrm{H}$ while in mineral soil it decreased with increasing soil depth. Tree biomass increased with increasing age in this pine age sequence and corresponded with increasing forest floor C. Soil organic C and N concentration however decreased for each stand age and natural forest with increasing soil depth from a mean of $36.9 \mathrm{~g}$ of $\mathrm{C} \mathrm{kg}^{-1}$ at $0-10 \mathrm{~cm}$ to about $19.4 \mathrm{~g}$ of $\mathrm{C} \mathrm{kg}^{-1}$ at $30-60 \mathrm{~cm}$ depth although there were deviations in the MW. 
Nitrogen followed similar trends from $2.1 \mathrm{~g}$ of $\mathrm{kg}^{-1}$ at $0-10 \mathrm{~cm}$ to $1.3 \mathrm{~g}$ of $\mathrm{N} \mathrm{kg}^{-1}$ at $30-60 \mathrm{~cm}$.

In pine plantations soil $C$ storage is maximised at 10 years and declines after thinning and gradually increases again towards the rotation age of 25 years. Thickness of litter layer did not have corresponding effect on the amounts of $\mathrm{C}$ stored in forest soils although there was positive correlation between litter layer and MaHF and fLF. Total $\mathrm{C}$ and $\mathrm{N}$ in bulk soil and density fractions generally decreased with increase in soil depth for all forest types and ages.

The contribution of fLF C, oLF C and MaHF C to SOC was $8-13 \%$, $1-7 \%$ and $90-91 \%$ respectively. The C:N ratios of SOM fractions decreased as: fLF > oLF > MaHF. Plantations can therefore be an efficient means of creating $C$ sinks owing to the rapid development rates soon after establishment and additions that come as the trees develop and grow into older age classes. Thus, the period of stand maturing between the age of 20 and 25 may be considered most important for $\mathrm{C}$ sequestration due to an increase in both the above and below ground $\mathrm{C}$ and $\mathrm{N}$ storage. If plantation forestry is to benefit from global arrangements such as REDD+, mitigation should aim at reducing disturbances such as fire and other forms of $C$ emissions. The focus should be on afforestation and enrichment planting to increase and maintain the area of forest land coupled with proper monitoring and silvicultural practices that increase $C$ sequestration. Maintenance of high conservation value moist forests has greatest benefits of both $C$ and biodiversity conservation and these should be conserved and if possible be considered as part of future REDD + projects. Additional studies are needed on biomass $C$ stocks.

\section{Acknowledgement}

We would to thank the Wattle company of Zimbabwe and staff at Nyanga timbers for technical assistance during field visits. We would like to thank the anonymous reviewers for their constructive comments and suggestions for improving this manuscript. The first author received a grant from the Netherlands Fellowship Programmes/PhD programme. Grant award CF 6677/2010.

\section{References}

Augustin, S., Katima, J., Klawe, E., Lyimo, B., 2007. The carbon offset verification model (COV). <http://globalcommunitywebnet.com/GlobalFiles/Augustin. html\#AA>.

Bens, O., Buczko, U., Sieber, S., Hüttl, R.F., 2006. Spatial variability of O layer thickness and humus forms under different pine beech-forest transformation stages in NE Germany. J. Plant Nutr. Soil Sci. 169, 5-15.

Black, K., Byrne, K.A., Mencuccini, M., Tobin, B., Neuwenhuis, M., Reidy, B., Bolger, T., Saiz, G., Green, C., Farrell, E.T., Osborne, B., 2009. Carbon stock and stock changes across a Sitka spruce chronosequence on surface-water gley soils. Forestry $82,3$.

Brown, S., 1997. Estimating biomass and biomass change of tropical forests: A primer. FAO Forestry Paper, vol.134. pp. 27.

Brown, S., 2002. Measuring carbon in forests: current status and future challenges. Environ. Pollut. 116, 363-372.

Brown, S., Lugo, A.E., Chapman, J., 1985. Biomass of tropical tree plantations and its implications for the global carbon budget. Can. J. For. Res. 16, 390-394.

Brown, S., Gillespie, A.J.R., Lugo, A.E., 1989. Biomass estimation methods for tropical forests with applications to forest inventory data. For. Sci. 35, 881-902.

Cannell, M.G.R., 1984. Woody biomass of forest stands. For. Ecol. Manage. 8, 299312.

Chan, K.Y., Cowie, A., Kelly, G., Bhupinderpal, S., Slavich, P., 2008. Scoping Paper: Soil Organic Carbon Sequestration Potential for Agriculture in NSW. NSW DPI Science \& Research Technical paper, 29.

Covington, W.W., 1981. Changes in the forest floor organic matter and nutrient content following clear cutting in northern hardwoods. Ecology 62, 41-48.

Currie, W.S., 1999. The responsive $\mathrm{C}$ and $\mathrm{N}$ biogeochemistry of the temperate forest floor. Trends Ecol. Evol. 14, 316-320.

Czimczik, C.I., Preston, C.M., Schmidt, M.W.I., Schulze, E.-D., 2003. How surface fire in Siberian Scots pine forests affects soil organic carbon in the forest floor: stocks, molecular structure, and conversion to black carbon (charcoal). Global Biogeochem. Cycles 17.
Dames, J.F., Scholes, M.C., Straker, C.J., 1998. Litter production and accumulation in Pinus patula plantations of the Mpumalanga Province, South Africa. Plant Soil 203, 183-190-190.

Dixon, R.K., Brown, S., Houghton, R.A., Solomon, A.M., Trexler, M.C., Wisniewski, J. 1994. Carbon pools and flux of global forest ecosystems. Science 263, 185-190.

Ecological Society of America, E., 2000. Carbon Sequestration in Soils.

Eliasson, P., 2007. Impacts of Climate Change on Carbon and Nitrogen Cycles in Boreal Forest Ecosystems. Doctoral thesis, Swedish University of Agricultural Sciences.

FAO, 1997. Estimating biomass and biomass change in tropical forests. FAO Forestry Paper 134, 55.

FAO, 2006. Fertilizer use by crop in Zimbabwe. FAO Rome. <http://www.fao.org/ docrep/009/a0395e/a0395e00.htm>. pp. 68.

Georgiadis, P., 2011. Accumulation of carbon and nitrogen in Swedish forest soils over stand age. MSc Thesis. Swedish University of Agricultural Sciences.

Golchin, A., Oades, J.M., Skjemstad, J.O., Clarke, P., 1994a. Study of free and occluded particulate organic matter in soils by solid state 13CP/MAS MNR Spectroscopy and scanning electron microscopy. Aust. J. Soil Res. 32, 285-309.

Golchin, A., Oades, J.M., Skjemstad, J.O., Clarke, P., 1994b. Soil structure and carbon cycling. Aust. J. Soil Res. 32, 1043-1068.

Gonzalez-Benecke, C.A., Martin, T.A., Cropper, W.P., Bracho, R., 2010. Forest management effects on in situ and ex situ slash pine forest carbon balance. For. Ecol. Manage. 260, 795-805.

Guo, L.B., Gifford, R.M., 2002. Soil carbon stocks and land use change: a meta analysis. Glob. Change Biol. 8, 345-360.

Hassink, J., 1995. Density fractions of soil macroorganic matter and microbial biomass as predictors of C and N mineralization. Soil Biol. Biochem. 27, 10991108.

Hoosbeek, M.R., Lukac, M., Velthorst, E., Smith, A.R., Godbold, D.L., 2011. Free atmospheric $\mathrm{CO}_{2}$ enrichment increased above ground biomass but did not affect symbiotic $\mathrm{N}_{2}$-fixation and soil carbon dynamics in a mixed deciduous stand in Wales. Biogeosciences 8, 353-364.

Hudiburg, T., Law, B., Turner, D.P., Campbell, J., Donato, D., Duane, M., 2009. Carbon dynamics of Oregon and Northern California forests and potential land-based carbon storage. Ecol. Appl. 19, 163-180.

IPCC, 2003. Good practice guidance for land use, land-use change and forestry. IPCCIGES, Japan.

Jandl, R., Lindner, M., Vesterdal, L., Bauwens, B., Baritz, R., Hagedorn, F., Johnson, D.W., Minkkinen, K., Byrne, K.A., 2007. How strongly can forest management influence soil carbon sequestration? Geoderma 137, 253-268.

Jiménez, J.J., Lorenz, K., Lal, R., 2011. Organic carbon and nitrogen in soil particlesize aggregates under dry tropical forests from Guanacaste, Costa Rica implications for within-site soil organic carbon stabilization. Catena 86, 178191.

Jobbagy, E.G., Jackson, R.B., 2000. The vertical distribution of soil organic carbon and its relation to climate and vegetation. Ecol. Appl. 10 (2), 423-436.

Kaye, J.P., Sigrid, C.P., Kaye, M.W., Chimer, R.A., 2000. Nutrient and carbon dynamics in a replacement series of Eucalyptus and albizia trees. Ecology 81 (12), 3267 3273.

Keith, D.M., Johnson, E.A., Valeo, C., 2010. Moisture cycles of the forest floor organic layer (F and $\mathrm{H}$ layers) during drying. Water Resour. Res. 46.

Kim, C., Jeong, J., Cho, H.S., Son, Y., 2010. Carbon and nitrogen status of litterfall, litter decomposition and soil in even-aged larch, red pine and rigitaeda pine plantations. J. Plant. Res. 123, 403-409.

Kundhlande, A., Nyakudya, I.W., Katsvanga, C., Wuta, M., Jimu, L., Gotosa, J., 2012 Influence of Pinus patula (Schltdl. \& Cham.) Plantations on dolerite soil properties in the Eastern Highlands of Zimbabwe: case of Erin Forest Estate. J. Horticult. For. 7 (1), 9-24.

Lal, R., 2003. Global potential of soil carbon sequestration to mitigate the greenhouse effect. Crit. Rev. Plant Sci. 22, 151-184.

Lamlom, S.H., Savidge, R.A., 2003. A reassessment of carbon content in wood: variation within and between 41 North American species. Biomass Bioenergy $25,381-388$.

Lewis, S.L., Lopez-Gonzalez, G., Sonké, B., Affum-Baffoe, K., Baker, T.R., Ojo, L.O., Phillips, O.L., Reitsma, J.M., White, L., Comiskey, J.A., Djuikouo K, M.N., Ewango, C.E.N., Feldpausch, T.R., Hamilton, A.C., Gloor, M., Hart, T., Hladik, A., Lloyd, J., Lovett, J.C., Makana, J.R., Malhi, Y., Mbago, F.M., Ndangalasi, H.J., Peacock, J., Peh, K.S.H., Sheil, D., Sunderland, T., Swaine, M.D., Taplin, J., Taylor, D., Thomas, S.C., Votere, R., Woell, H., 2009. Increasing carbon storage in intact African tropical forests. Nature 457, 1003-1006.

Li, X., Yi, M.J., Son, Y.H., Park, P.S., Lee, K.H., Son, Y.M., Kim, R.H., Jeong, M.J., 2011 Biomass and carbon storage in an age - sequence of Korean Pine (Pinus koraiensis ) plantation forests in central Korea. Journal of Plant Biology 54, 3342.

Liao, C., Luo, Y., Fang, C., Chen, J., Li, B., 2012. The effects of plantation practice on soil properties based on the comparison between natural and planted forests: a meta analysis. Glob. Ecol. Biogeogr. 21 (3), 318-327.

Malimbwi, R.E., Solberg, B., Luoga, E., 1994. Estimation of biomass and volume in miombo woodland at Kitulangalo Forest Reserve. Tanzania J. Trop. For. Sci. 7, $230-242$.

Marris, E., 2008. Old forests capture plenty of carbon. Nature. http://dx.doi.org/ 10.1038/news.2008.1092.

Matos, E.S., Freese, D., Ślazak, A., Bachmann, U., Veste, M., Hüttl, R.F., 2010. Organiccarbon and nitrogen stocks and organic-carbon fractions in soil under mixed pine and oak forest stands of different ages in NE Germany. J. Plant Nutr. Soil Sci. 173, 654-661. 
Muneri, A., Balodis, V., 1998. Variation in wood density and tracheid length in Pinus patula grown in Zimbabwe. Southern Afr. For. J. 182, 41-50.

Nilsson, S., Schopfhauser, W., 1995. The carbon-sequestration potential of a global afforestation program. Clim. Change 30, 267-293.

Noh, N.J., San, Y.H., Lee, K.S., Yoon, T.K., Seo, K.W., Kim, C.S., Lee, W.K., Bae, S.W., Hwang, J.H., 2010. Influence of stand density on soil $\mathrm{CO}_{2}$ efflux for Pinus densiflora forest in Korea. J. Plant Res. 123, 411-419.

Olsson, B.A., Staaf, H., Lundkvist, H., Bengtsson, J., Rosen, K., 1996. Carbon and nitrogen in coniferous forest soils after clear-felling and harvests of different intensity. For. Ecol. Manage. 82, 19-32.

Parfitt, R.L., Ross, D.J., 2011. Long term effects of afforestation with Pinus radiata on soil carbon, nitrogen and pH: a case study. Soil Res. 49 (6), 494-503.

Peichl, M., Arain, M.A., 2006. Above ground and below ground ecosystem biomass carbon pools in an age sequeance of temperate pine plantation forests. Agr. For. Meteorol. 140, 51-63.

Peltoniemi, M., Makipaa, R., Liski, J., Tamminen, P., 2004. Changes in soil in soil carbon with stand age - an evaluation of a modelling method with empirical data. Glob. Change Biol. 10.

Penne, C., Ahrends, B., Deurer, M., Böttcher, J., 2010. The impact of the canopy structure on the spatial variability in forest floor carbon stocks. Geoderma 158, 282-297.

Richter, D.D., Markewitz, D., Trumbore, S.E., Wells, C.G., 1999. Rapid accumulation and turnover of soil carbon in a re-establishing forest. Nature 400, 56-58.

Rita, J.C.O., Gama-Rodrigues, E.F., Gama-Rodrigues, A.C., Polidoro, J.C., Machado, R.C.R., Baligar, V.C., 2011. C and N content in density fractions of whole soil and soil size fraction under cacao agroforestry systems and natural forest in Bahia, Brazil. Environ. Manage.. http://dx.doi.org/10.1007/s00267-011-9642-3.

Roscoe, R., Buurman, P., Velthost, E.J., Pereira, J.A.A., 2000. Effects of fire on soil organic matter in cerrado sensu stricto' from Southeast Brazil as revealed by changes in 813 C. Geoderma 95, 141-160.

Ryan, C.M., Williams, M., Grace, G., 2011. Above- and belowground carbon stocks in a Miombo woodland landscape of Mozambique. Biotropica 43 (4), 423-432.

Schulp, C., Nabuurs, G., Verburg, P., Dewaal, R., 2008. Effect of tree species on carbon stocks in forest floor and mineral soil and implications for soil carbon inventories. For. Ecol. Manage. 256, 482-490.

Schwertmann, U., Kodama, H., Ficher, W.R., 1986. Mutual interactions between organics and iron oxides. In: Huang, P.M., Schnitzer, M. (Eds.), Interactions of Soil Minerals with Natural Organics and Microbes. SSSA, Madison, WI, pp. 223-250.

Seely, B., Welham, C., Kimmins, H., 2002. Carbon sequestration in a boreal forest ecosystem: results from the ecosystem simulation model, FORECAST. For. Ecol. Manage. 169, 123-135.

Sharrow, S.H., Ismail, S., 2004. Carbon and nitrogen storage in western Oregon agroforests, forests, and pastures. Agrofor. Syst. 60, 123-130.

Shirima, D.D., Munishi, P.K.T. Lewis, S.L., Burgess, N.D., Marshall, A.R., Balmford, A Swetnam, R.D., Zahabu, E.M., 2011. Carbon storage, structure and composition of miombo woodlands in Tanzania's Eastern Arc Mountains. African Journal of Ecology 49, 332-342.

Shrestha, B.M., Chen, H.Y.H., 2010. Effects of stand age, wildfire and clearcut harvesting on forest floor in boreal mixedwood forests. Plant and Soil 336, $267-$ 277.

Starr, M., Saarsalmi, A., Hokkanen, T., Merila, P., Helmisaari, H.S., 2005. Models of litterfall production for Scots pine (Pinus sylvestris L.) in Finland using stand, site and climate factors. For. Ecol. Manage. 205, 215-225.

Tan, Z., Lal, R., Owens, L., Izaurralde, R.C., 2007. Distribution of light and heavy fractions of soil organic carbon as related to land use and tillage practice. Soil Tillage Res. 92, 53-59.

Taylor, A.R., Wang, J.R., Chen, H.Y.H., 2007. Carbon storage in chronosequence of red spruce (Picea rubens) forest in central Nova Scotia. Canada. Can. J. For. Res. 37, 2260-2269.

Trumbore, S.E., Chadwick, O.A., Amundson, R., 1996. Rapid exchange between soil carbon and atmospheric carbon dioxide driven by temperature change. Science 272, 393-396.

Usuga, J.C.L., Toro, J.A.R., Alzate, M.V.R., de Jesús Lema Tapias, Á., 2010. Estimation of biomass and carbon stocks in plants, soil and forest floor in different tropical forests. For. Ecol. Manage. 260, 1906-1913.

van Bodegom, A., van den Berg, Y., van der Meer, P., 2008. Forest plantations for sustainable production in the tropics. Wageningen University and Research Centre, The Netherlands, 978-90-8585-231-5. <http://www.cdic.wur.nl/NR/ rdonlyres/DFDA8928-9664-4EF3-A593-C5E3023D3164/68149/Rapport>_.

Van Minnen, J.G., 2008. The terrestrial carbon cycle on the regional and global scale. Modeling, uncertainties and policy relevance. doctoral thesis, Wageningen University.

Vesterdal, L., Ritter, E., Gundersen, P., 2002. Change in soil organic carbon following afforestation of former arable land. For. Ecol. Manage. 169, 137-147.

von Lützow, M., Kögel-Knabner, I., Ekschmitt, K., Matzner, E., Guggenberger, G., Marschner, B., Flessa, H., 2006. Stabilization of organic matter in temperate soils: mechanisms and their relevance under different soil conditions-a review. Eur. J. Soil Sci. 57, 426-445.

WATCO, 2010. Overviwe ann Management Plan of the Pine Estates. Wattle Company Limited.

Wendling, B., Jucksch, I., Mendonça, E.S., Alvarenga, R.C., 2010. Organic-matter pools of soil under pines and annual cultures. Commun. Soil Sci. Plant Anal. 41 (14), 1707-1722.

Yang, Y., Luo, Y., 2011. Carbon:nitrogen stoichiometry in forest ecosystems during stand development. Glob. Ecol. Biogeogr. 20, 354-361.

Zhang, P., Zhang, T., Chen, N.L., 2009. Vertical distribution patterns of soil organic carbon and total nitrogen and related affecting factors along northern slope of Qilian Mountains. Chin. J. Appl. Ecol. 20, 518-524. 